\title{
The innovation systems approach: an Austrian and Ostromian perspective
}

\section{Paul Lewis ${ }^{1}$}

Published online: 23 April 2020

(C) The Author(s) 2020

\begin{abstract}
The innovation systems (IS) approach - developed by Richard Nelson, Christopher Freeman and Bengt-Ake Lundvall, amongst others - has become perhaps the dominant approach in the academic literature for the study of innovation. It has also exerted considerable influence on policy. This paper examines both the theory underpinning the IS approach, which bears considerable affinities with Austrian economics, and also its policy implications. It is argued that the work of Friedrich Hayek and Elinor Ostrom in particular can be used to draw attention to some potential difficulties with the way in which the IS approach is often used to guide policy. Ideas drawn from Austrian economics, as well as the work of Elinor Ostrom, are used to help develop and improve the IS approach, both theoretically and in terms of its approach to policy.
\end{abstract}

Keywords Innovation · Innovation systems · Complexity · Rules · Uncertainty · Polycentricity

\section{Introduction}

One of the most interesting and influential approaches to innovation, and innovation policy, over the past thirty years had been the innovation systems (IS) approach. According to the latter, innovation involves the generation and widespread diffusion of knowledge about new products and methods of production. This is said to occur via a complex, non-linear process involving interactions between firms and other organisations (including universities, banks, technical standard institutes, and government). It follows that the performance of an economy in respect of innovation depends critically upon the institutions (rules) governing those interactions (Freeman 1987, Lundvall, [ed.] Lundvall 1992, Dosi et al. [eds.] Dosi et al. 1988, Nelson [ed.] Nelson 1993).

Paul Lewis

paul.lewis@kcl.ac.uk

1 Department of Political Economy, King's College London Bush House (NE), Aldwych, London WC2R 2LS, UK 
Where the rules in question impede rather than facilitate interactions of the relevant kind, 'system failures' are said to occur, in the sense that reliance on a different set of rules might make it possible for the economy to perform better when it comes to generating and disseminating knowledge of new goods and technologies. This is said to give rise to a rationale for government policy that is arguably quite distinct from neoclassical accounts for intervention based on the notion of market failure, being based on shaping the institutional environment within which innovation occurs rather than intervening directly in the innovation process (Smith 2000; Metcalfe 2005, 2007: 447; Edler and Fagerberg 2017; Weber and Truffler 2017: 112. In that respect, the system failure approach to policy may share a good deal in common with the views of the Austrian and Bloomington schools, both of which also suggest that government policy ought largely to be confined to establishing the over-arching framework of rules within which economic activity occurs. However, while the IS approach shares a similar view of the economic process to Austrian economics, the work of the Austrian school, and also of Elinor Ostrom, also suggests that the IS approach to policy may nevertheless have under-estimated the informational demands its 'systems-based' approach makes upon policy-makers.

The structure of the paper is as follows. Section 2 discusses the nature of innovation and outlines the IS approach. Section 3 compares the IS and Austrian views of the economics process, while Section 4 uses the work of Hayek and Elinor Ostrom to highlight some potential shortcomings of the IS approach to policy. Section 5 summarises and draws conclusions.

\section{Innovation and the innovation systems approach}

Innovation is the process whereby new technologies are created and diffuse throughout the economy so as to create new commercially-viable products and novel methods of producing existing goods and services. It is the means through which new knowledge is created and applied to economic processes in order to increase productivity and add value to economic activity. As such, it is the engine of long-term economic growth and development (OECD 1997a: 47, OECD 2005: 46-52; BIS 2011: 1, 7-22).

An important theoretical framework for understanding innovation, which is influential both in academia and also amongst policy-makers, is the innovation systems (IS) approach. The key insights of this approach, which was developed in the late 1980s and early 1990s, are twofold. First, innovation is a non-linear process. Second, the working of that process, and therefore the extent and kind of innovation that takes place, is crucially shaped by the institutions governing how the firms and other organisations involved in innovation interact with one another (Freeman 1987; Dosi et al. 1988; Lundvall 1992; and Nelson and Rosenberg 1993). We shall consider each of those topics below, before moving on to consider the policy implications to which the IS approach leads.

\subsection{A non-linear view of innovation}

The IS approach is based on the idea that far from being a linear process, whereby new knowledge is created through basic scientific research and then applied to create novel 
products and production processes, innovation is in fact non-linear in nature, centring on complicated feedback mechanisms and interactive relations involving science, technology, production, and use. Two stylised facts support this non-linear view.

- First, case studies indicate that, far from always involving the application of given scientific knowledge, technological innovations have in fact often taken place before the development of the relevant scientific theory, being based on practical rather than scientific knowledge. Indeed, by drawing attention gaps in basic knowledge, technological developments have at times actually driven the growth of science, as for example when thermodynamics was developed to understand the factors determining the efficiency of steam engines. On this view, technological developments occurring in the later stages of the innovation process can help to shape basic scientific research, undermining the linear model's claim that scientific advances always precede and drive technological change (Rosenberg 1982: 14159; Nelson and Rosenberg 1993: 6-9; Dosi and Nelson 2018: 42-43).

- Second, evidence also shows that requests and recommendations made by actual and/or potential users of new products and technologies, especially early or 'lead' users, are often fed back into the research process, informing the learning involved in innovation (Rosenberg 1982: 193-241; von Hippel 1988, 2015; Dosi and Nelson 2018: 46-47, 67-68).

These stylised facts indicate that the learning through which the new knowledge involved in innovation is generated derives from several sources, located at various stages in the innovation process (rather than just from pure scientific research) (Kline and Rosenberg 1986; Fagerberg 2017: 499-502).

On this view, innovation is a complex, non-linear process of knowledge creation and diffusion, involving interactions between firms and several other kinds of organisation (including customers and organisations involved in scientific knowledge creation, such as universities and government research institutes). Those other organisations serveas we shall see-as sources of the information, finance, skills, and other resources required for new knowledge to be developed and to diffuse through the economy. And if it is indeed the case that innovation involves interactions between a variety of organisations, then in order to understand it, it will be necessary to analyse the institutions that govern those interactions and thereby shape knowledge creation and diffusion. ${ }^{1}$

\subsection{The importance of institutions}

The non-linear view of innovation suggests that when firms innovate, they rarely if ever act in isolation. Rather, they interact with other organisations in order to generate, acquire, and develop the knowledge used to develop and deploy new products and technologies. Those organisations will often be other firms; but they will also frequently include universities, banks, government departments, regulatory agencies, venture capital funds, technical standards institutions, schools, and other providers of education

\footnotetext{
${ }^{1}$ For related accounts of science as a spontaneous order, produced through a polycentric process, see McQuade and Butos (2003), Mcquade (2010: 36-53) and Tarko (2015).
} 
and training, to name but a few. Those organisations act as sources of knowledge, finance, skills, and other kinds of resource, thereby contributing to the process through which innovation takes place.

The organisations in question, along with the institutions that govern their interactions, constitute what is known as an innovation system (Edquist 1997a, 1997b). As one of the founders of the IS approach, Bengt-Åke Lundvall, has put it, "A system of innovation is constituted by elements and relationships which interact in the product, diffusion and use of new and economically useful knowledge" (Lundvall 1992: 2). In a similar vein, another prominent contributor to the literature, Charles Edquist, has stated that, "Innovation processes ... occur in interaction between institutional and organisational elements which together may be called 'systems of innovation"" (1997a: xiii). The elements or parts of the system are the organisations that contribute to innovation; while the institutions are the rules that govern how those organisations interact with each other. The institutions or rules in question include:

- financial rules, such as accounting standards and rules of corporate governance;

- legal rules, relating to contracts, employment and perhaps most notably intellectual property;

- risk-management rules;

- rules governing the application of various kinds of technical standards;

- environmental, and health and safety, regulations, which influence the demand for certain kinds of technology; and

- rules governing public procurement, which also help to shape the demand for innovative technologies and goods.

By structuring how firms interact with each other, and with the other organisations that contribute to the innovation process, these institutions or rules are an important influence on the quantity and kind of innovation - understood as learning about new products and methods of production - that takes place (Lundvall and Johnson 1994). As summarised by one of the pioneers of the innovations system approach, Stan Metcalfe, a system of innovation is "that set of institutions which jointly and individually contribute to the development and diffusion of new technologies ... As such it is a system of interconnected [organisations] to create, store and transfer the knowledge, skills and artefacts which define new technologies" (Metcalfe 1995: 38). ${ }^{2}$

An innovation system is a genuine system, therefore, in the sense that its operation depends not just on its constituent parts - the organisations involved in innovationbut also the institutional rules governing how those parts relate to and interact with one another. ${ }^{3}$ It is the interconnected set of organisations that constitutes the environment within which innovation occurs, with the connections between organisations shaping how knowledge is developed and diffuses through the economy and thereby determining both the extent and the kind of innovation that takes place. And it is the way the organisations involved in innovation interact with each other, conditioning one

\footnotetext{
${ }^{2}$ Also see: Freeman 1987: 1; Lundvall 1992: 9, 12; Woolthius et al. 2005: 610-11; Edquist 2005: 182, 18788; Metcalfe 2007: 447-48.

${ }^{3}$ For more on the underlying notion of a 'system', see Nelson and Rosenberg (1993: 4-5), Metcalfe (2005: 63-68), Metcalfe et al. (2006: 8-11), and Lewis (2016: 130-32, 2017: 38-40).
} 
another's behaviour and thereby facilitating or impeding the development, use and diffusion of knowledge, that the notion of a system is meant to capture (Edquist 1997b; Smith 2000: 73-74; Metcalfe 2007: 447). ${ }^{4}$

The key question that may be asked of such systems, therefore, concerns the extent to which they generate the information and incentives required to encourage and enable firms successfully to innovate by accumulating and putting into practice at a commercial scale new products and methods of production. Considering this question gives rise to the question of what role, if any, there is for government policy to support innovation. As we shall see below, the IS approach gives rise to a set of arguments in favour of government intervention that are quite distinct from those sustained by standard, neoclassical economics.

\subsection{The 'system theoretic' rationale for government intervention}

The IS literature focuses on how the institutions governing the interactions between firms and other organisations constrain and enable innovation. This approach gives rise to the notion of 'system failure'. 5 System failures arise when the institutions in question fail to disseminate the information and other resources, and to coordinate the activities, required to ensure that new technologies are developed and diffuse properly through the economy. This may be because some of the relevant organisations or elements of the system are absent, or because some of the connections linking them are missing or inadequate, so that the informational and other resources required for innovation are not available in sufficient quantities. As one prominent contributor to this literature has put it, "A system may fail to operate in the desired way because knowledgeable actors are missing, because connections are absent or because system boundaries are drawn in the wrong place. Attention to these issues provides the basic rationales for innovation systems policy" (Metcalfe 2007: 447; also see Metcalfe 2005: 54-63, 2007: 447-48; Smith 2000: 93-100; Edler and Fagerberg 2017: 5, 8-10; Weber and Truffler 2017: 112).

For instance, if the legal rules governing intellectual property are too lax, then organisations may doubt that they will earn a sufficient return on their investment in developing new products and production techniques, deterring them from making such investments and thereby deterring innovation. But if the rules are too harsh, then the diffusion of knowledge required for innovation will be impeded. To take a second example, if a country's system of corporate governance - the rules governing the provision of finance and the possibility of takeovers - is such that firms rely heavily on equity capital and have to focus on the short-run price of their shares, then they may be reluctant to undertake the long-term investments required to support innovative

\footnotetext{
${ }^{4}$ The innovation systems approach is 'holistic' because, by paying attention to the causal and explanatory significance of the social relations obtaining between the various actors involved in innovation, it accords significant causal and explanatory weight to the institutional rules that shape those relations. In particular, this emphasis on the rules that structure and govern how the various organisations that contribute to the innovation process interact with each other means that the innovation systems approach stands in contrast to reductionist approaches that try to analyse social phenomena in terms of the behaviour and properties of isolated individual actors (Edquist 1997b: 17-18; Chaminde and Edquist 2010: 100; Dias et al. 2014: 1072; Weber and Truffler 2017: 104, 113-15).

${ }^{5}$ The notion of system failure is, as will be explained below, quite distinct from the conventional notion of market failure associated with neoclassical economics.
} 
activities. Third, if the rules governing the activities of the organisations involved in education and training are inappropriate, then they may impede rather than promote the effective coordination of physical and human capital, leaving firms with an inadequate supply of the skilled workers institutions required effectively to deploy new technologies (Woolthius et al. 2005: 613; BIS 2011: 29; Vona and Consoli 2014; Lewis 2019, 2020).

The possibility of such 'systemic' problems implies a possible role for the state in improving the institutional framework within which innovation takes place (Metcalfe 2007: 448-52; Edler and Fagerberg 2017: 9-10). Just as system failures may reflect the fact that some of the relevant organisations may be missing entirely, or that they are governed by rules that discourage them from doing what is required to generate and use new technologies, so too there are two broad sets of policy responses. Policy can focus on the organisations that are the elements in the system, through the creation of 'missing' organisations or by building their individual capabilities to develop and exploit innovations; or it can focus on the rules governing how those organisations interact with each other-i.e., it can focus on the connections between the elements, rather than the elements themselves - by seeking to bring the different organisations together to facilitate more effective development, diffusion, and use of knowledge (Edler and Fagerberg 2017: 5; Fagerberg 2017: 502).

The IS literature has acquired a significant following amongst policy-makers, not least because of its adoption by the OECD (1997b, 1999, 2002). It has also received attention from policy-makers in the UK (see, for example, BIS 2011: 10, 28-30; DBIS 2014: 11-26; Government Economic Service 2014). As least part of its appeal derives from the fact that - compared to neoclassical approaches to policy-it encompasses a greater range of influences on innovation and so affords policy-makers a wider scope for possible policy intervention (Mytelka and Smith 2002; Sharif 2006; Weber and Truffler 2017: 106-09).

\section{The innovation systems approach and AUSTRIAN economics: A comparison}

\subsection{The economy of an evolutionary process}

It is worth noting at this juncture that the IS approach is based on a conception of markets and the economy that is quite distinct from neoclassical economics, but which resembles closely the vision of the economic life espoused by Austrian economists. The similarities between the IS approach and Austrian economics will be outlined in this section.

One of the main factors encouraging the development of the IS approach was the belief that standard neoclassical economics, with its emphasis on static equilibria, was incapable of doing justice to innovation, which is of course a dynamic, non-equilibrium phenomenon (Sharif 2006; Weber and Truffer 2017: 103-04; Nelson 2018: 2-12). The reason is that the IS approach is based on a view of the economy as a dynamic process of evolutionary competition and change. A key contribution in this respect was made one of the founders of the IS approach, namely Richard Nelson, who along with co- 
author Sidney Winter set out in 1982 an influential evolutionary perspective on the economy. According to Nelson and Winter, economic behaviour is guided by rules or routines that develop through a dynamic, non-equilibrium process of variation, selection, and replication or inheritance (e.g. Nelson and Winter 1982: 14-19, 96-136; also see Nelson 2018: 14-19). A firm's routines are thought to embody its knowledge about how to do things. The practical or tacit knowledge embedded in those routines concerns not only how to carry out production but also about how to solve problems in the production process and how to search for and develop new knowledge. Those routines are the analogue in Nelson's and Winter's evolutionary model of the economy to the gene in models of biological evolution, in the sense that both serve as durable repositories of (tacit) knowledge that can be replicated over time (Nelson and Winter 1982: 134-36).

This cn biology, economic evolution has three essential features.

- First, there must be variation between the members of the relevant population (the species, in the case of biological evolution, or the set of firms, in the case of the economy). That variation may arise by chance, as is often the case in natural selection, or it may be the result of the purposeful action, as when an entrepreneur develops a novel method of-i.e., new routines/rules for-production (Nelson and Winter 1982: 17-18, 128-32).

- Second, there needs to be a process of selection, whereby members of the population that are 'fitter' or better adapted to their environment are able to increase in number. In the natural world, species that are better adapted to their habitat are able to leave increased numbers of offspring, thereby growing in number, while those that are less well adapted decline in number and eventually die out. In the economic realm, firms that 'fit' their market because they (utilise routines that enable them to) produce at reasonable cost goods and services that their customers want to buy earn profits and are therefore able to grow in size, while firms that do not suffer losses and either improve or eventually go out of business (Nelson and Winter 1982: 4, 9, 16-17; Nelson 2018: 6-7).

- Third, there has to be some means through which the attributes of the successful parents are passed on to their progeny. This brings us back to the analogy between the gene, which acts as the relevant vehicle in the case of biological evolution, and organisational routines, which act as a repository of knowledge about how to produce goods and services. Such routines are the 'organisational memory' of the firm, passing down knowledge of how to engage in productive activities over time. They may also be imitated by other firms, further enhancing their ability to transmit information in a manner analogous to the gene (Nelson and Winter 1982: 14-15, 117-124).

Nelson and Winter's approach has been widely adopted in the IS literature. On this view, innovation plays a central role in economic life, as the source of the variation in routines and behaviour that gives different firms different advantages in the process of rivalrous market competition. Those patterns of relative advantage and disadvantage 
resolve themselves into differences in relative profitability and, ultimately, growth rates as firms either succeed and grow, or fail and close down. The feedback provided by profit and loss accounts, and the way that this leads to a process of selection whereby unprofitable enterprises are eliminated while profitable ones attract more resources and grow, contributes to the efficiency-enhancing aspects of the market process. Overall, this evolutionary perspective suggests that if markets are working well, then firms with superior knowledge and capabilities are able to grow at the expense of less competitive rivals. This is the central dynamic of economic competition, viewed as a dynamic evolutionary process, and it is the task of policy to promote it (Metcalfe 2005: 61; Edler and Fagerberg 2017: 10).

It is also worth noting that the neoclassical and IS approaches can give rise to policy implications that are not only different but also sometimes quite contradictory (Metcalfe 2005: 54-60, Metcalfe 2007: 446, 452; also see Chaminde and Edquist 2010: 100-02, $105){ }^{6}$ The reason is that where innovation is viewed as taking place via a dynamic, evolutionary processes, many of the features of the economy that are viewed as objectionable from a neoclassical point of view, with its focus on static equilibria, come to be seen as necessary counterparts to the process of knowledge creation and diffusion through which innovation takes place. Two examples will be mentioned here: market power; and asymmetric information. The IS approach suggests that a measure of monopoly power - which is viewed as detrimental to the social good from the vantage point provided by static neoclassical theory - is actually necessary for innovation, because it helps to ensure that firms gain a return on their investment. What matters for the successful performance of an economy viewed as an innovation system is not that it should approximate some hypothetical state of perfect competition, as the neoclassical model implies, but rather that firms should be free to enter and exit markets (so as to encourage the rivalrous competition that spurs firms to develop and deploy new technology).

Something similar is also true of asymmetric information, which — rather than being treated simply as a cause of market failure, as it is by neoclassical economics - is according to the IS approach necessary for innovation; for without privileged access to information a firm would see its new ideas immediately identified and replicated by their rivals, denying it the opportunity to profit from them and thus eliminating the incentive to innovate in the first place. "It is surely perverse to label as market failures phenomena that are integral to the competitive market process and which give modern

\footnotetext{
${ }^{6}$ The standard, neoclassical case for government intervention to support innovation is based on the old, linear view, according to which new knowledge is created through basic scientific research and then applied, more or less automatically, to develop novel products and processes. Standard neoclassical economics suggests that market failures deriving from the limited appropriability of that knowledge will mean that too little knowledge creation - and, therefore, too little innovation - will take place. Policy responses to his problem can include the use of subsidies for research in non-governmental research institutions such as universities and the establishment of a system of patents to protect the intellectual property created by R\&D (Nelson 1959; Arrow 1962; also see Edler and Fagerberg 2017: 6-8; and Dosi and Nelson 2018: 50-57).

${ }^{7}$ For the reasons just explained, the IS approach can yield very different policy implications to neoclassical economics. Accordingly, some strands of the IS literature reject the neoclassical account of market failure, viewing the notion of 'system failure' as providing a quite distinct rationale for intervention (Metcalfe 2005, 2007: 446, 452; Chaminde and Edquist 2010). Other strands of the IS literature seem, however, to view the two notions of failure as being complementary, with the conventional notion of market failure overlapping and possibly even being a subset of the notion of system failure (Schmidt 2018). In what follows we focus on the former strand of the IS literature.
} 
capitalism its unique dynamic properties”, Metcalfe (2005: 57, 58, 61-62) states, continuing that: "The imperfections identified in the market failure approach are to be viewed now as integral and necessary aspects of the production and dissemination of knowledge in a market economy. ... [W]ithout asymmetries of knowledge and the correlated uncertainties and indivisibilities the competitive process has nothing with which to work. The quasi-public good nature of knowledge, indivisibility and increasing returns, the inherent uncertainties of creative, trial and error processes and the imperfect nature of property rights are essential if knowledge if market capitalism is to function. They are not imperfections to be corrected by policy."

\subsection{Comparison with Austrian economics}

These features of the IS approach's account of the economic process mean that it resembles Austrian economics in several important ways. The Austrian account of the market process is too well known to readers of this journal to require recapitulation here (Hayek 1945 2014, [Hayek 1968] 2014, Hayek 1976: 10; Kirzner 1992, 2000; Harper and Endres 2016; Harper 2018). Instead, the main points of similarity between Austrian economics and the IS approach will be listed below:

- First, like Austrian economics, the IS approach's emphasis is - as we have seenon the inherently dynamic and processual nature of economic activity, not on static equilibria.

- Second, and again like Austrian economics, the IS approach treats novelty and change as occurring endogenously, as an integral part of the evolutionary process through which the economy is thought to develop (rather than - as in neoclassical economics - arising only through exogenous shocks).

- Third, both Austrian economics and the IS approach assume that knowledge is dispersed or distributed between the various actors in the system (Metcalfe and Ramlogan 2004; 658-59, 666-67; Antoneli 2017: 696). Indeed, it is precisely because knowledge is fragmented that advocates of the IS approach believe that organisations need to interact with each other if they are to innovate. The IS approach also shares with Austrian economists like Hayek a belief in the importance of tacit knowledge (in particular, that embedded in firms' routines) (Nelson 1980: 64-66; Nelson and Winter 1982: 76-82; Dosi 1988: 1125-31; Metcalfe and Ramlogan 2004; Smith 2000: 77-83, 89-90).

- Fourth, both the IS approach and Austrian economics are sceptical about standard neoclassical accounts of market failure, arguing that notions such as perfect competition and Pareto efficiency fail to do justice to the significance of markets as dynamic processes of discovery through which people learning about new goods, preferences and technologies (Hayek 1948 2014, [Hayek 1968] 2014; Metcalfe 2005: 54-60, Metcalfe 2007: 446, 452). Indeed, at least some exponents of both approaches have argued that there ought to be a departure from the idea that policy should aim for some ideal or optimal state of affairs, rejecting the notion of market or system 'failure' as presupposing an unrealistic and so unattainable benchmark in favour of a more comparative approach that seeks to compare the capacity of 
different systems of rules to deal with system 'problems' (Chaminde and Edquist 2010: 101-05, 108; Bergek et al. 2010; Lewis 2013; Furton and Martin 2019).

- Fifth, and most significantly for what follows, like Austrians such as Hayek, the IS approach conceptualises the economy as a complex (innovation) system. The system is composed of a set of parts - people and organisations - whose interactions are structured by certain rules. The system therefore has a particular structure and displays various properties - such as the power to coordinate people's plans and to generate and diffuse knowledge about new products and methods of production - that are not possessed by any of its parts taken in isolation. Those emergent properties, as they are known, are often the outcome of a process of selforganisation, arising from the rule-guided responses of the individual parts to their immediate surroundings rather than as the result of orders issued by a central controller possessing an over-arching, synoptic view of the system as a whole. The system evolves through a process of multi-level selection (Hayek 1967 2014; Harper and Lewis 2012; Lewis 2015; Metcalfe and Ramlogan 2004; Dias et al. 2014, Antoneli 2017).

- Sixth, those emergent properties are often novel in the sense that they could not have been predicted ex ante, given people's knowledge of the properties of the component parts. Therefore, their occurrence may well be a genuine surprise in that it lies outside the confines of what people had hitherto imagined might happen. As a result, people in complex-systems are not always choosing between well-defined alternatives and therefore are often unable to act in the expected-utility maximizing fashion assumed by rational choice theory (Nelson and Winter 1982 8, 31-36, 41; Dosi 1988: 1134; Metcalfe 2007: 445; Metcalfe and Ramlogan 2004: 661; Nelson 2018: 4; 17).

There is, then, a good deal of common ground between the Austrian and IS approaches, centring on their view of how the economy ought to be conceived and understood. However, notwithstanding such similarities, there are also differences, in particular concerning the scope for policy favourably to affect the processes through which innovation takes place. These differences stem at least in part from the way in which both Austrians like Hayek, and also members of the Bloomington School such as Elinor Ostrom, conceptualise the (interactions between) social rules of the kind that help to make up the innovation system. As we shall see, both Hayek and the Ostroms offer reasons for thinking that it might not be entirely straightforward for policy-makers to understand how those rules combine to shape economic activity, including innovation. This may impose limits on the extent to which it is advisable for policy-makers to attempt to improve the innovation process by altering those rules, as the IS approach suggests policy-makers ought to consider doing.

\section{The innovation systems approach to policy: An Austrian/Ostromian perspective}

For all the merits and advantages of the IS approach, and there are many, authors working that in tradition have acknowledged various difficulties with using it as a basis for policy. For example, an early and widely cited analysis of the policy 
implications of the approach noted that innovation systems are "are likely to be quite specific in terms of institutional frameworks, industrial structures and technological bases":

These specificities must be taken account of in policy design. Their existence seems to suggest that 'neutral' policies are likely to be so abstract that they have little effect within the distinct structures of specific systems. Policies should therefore be designed with system specificities in mind. This imposes fairly substantial analytical demands (both statistical and otherwise) regardless of whether policies are being made at central level or regional level. Policies in support of innovation and technological change need rather precise identification of how system knowledge bases are actually constructed. This is not at all a simple matter: even the knowledge bases of apparently simple industries rest on the articulation of quite different knowledges, and interactions between quite different institutional forms. (Smith 2000: 98).

Similar problems were also noted in a more recent survey of the innovation systems approach, published some seventeen years after the article just quoted, where it is acknowledged that "one of the core problems [of the IS approach to policy] ... is that, in general, a myriad of constellations of system elements could lead to similar levels of innovation success, while similar constellations could lead to widely varying outcomes depending on the context conditions" (Weber and Truffler 2017: 113). Another recent survey reports that studies of the effects of innovation policy "identified a large number of variables influencing the impact of innovation policy instruments, such as interaction with other instruments (which policy-makers often tended to be unaware of)" (Edler and Fagerberg 2017: 14).

One way of thinking about the difficulties to which these authors are drawing attention is to suggest that they stem from a feature of complex social systems to which both Hayek and Elinor Ostrom draw attention, namely that the emergent properties of those system arise only when the interactions between their parts are governed by the relevant set or system of institutions or rules $\left\{\mathrm{r}_{1}, \mathrm{r}_{2}, \ldots, \mathrm{r}_{\mathrm{n}}\right\}$. Emergent social properties, such as the capacity to coordinate people's plans and to generate and diffuse knowledge about new technologies and products through the economy, are neither the result of just one specific rule $\mathrm{r}_{1}$, nor are they simply the sum of the separate effects of each of those rules taken in isolation. Rather, they arise from the causal interaction between a set of interdependent rules, situated in a particular environment (E), whereby individual rules have a different impact on outcomes depending on the other rules with which they are combined. A system's emergent properties are therefore a non-additive function of the relevant rules $\left\{\mathrm{r}_{1}, \mathrm{r}_{2}, \ldots, \mathrm{r}_{\mathrm{n}}\right\}$. This is an example of holism, in the sense that the functioning and consequences of any one rule depends on the other rules in the system of which it is a part. ${ }^{8}$ Hence Hayek's remark that, "systems of rules of conduct will develop as wholes" ([Hayek [1967] 2014: 283), which for him means that "any given rules of individual conduct may prove beneficial as part of one

\footnotetext{
${ }^{8}$ Rules whose functioning and causal consequences are interdependent are sometimes also said to be "tightly coupled" (Levinthal 1997: 936).
} 
set of such rules, or in one set of external circumstances, and harmful as part of another set of rules or in another set of external circumstances" (Hayek 1967 2014: 280). This creates difficulties for policy-makers, because it makes it harder for them to identify appropriate policies. Where rules are mutually interdependent or tightly coupled, a change in any one rule $r_{1}$ can affect the functioning and causal impact of some or all of the other rules $\left\{r_{2}, \ldots, r_{n}\right)$, reverberating through the system and thereby changing the outcomes it produces in surprising ways, not least by producing unintended consequences that policy-makers simply could not anticipate. All this makes successful manipulation of the system highly problematic (Gaus 2007).

Elinor Ostrom make similar points, albeit using slightly different terminology, in her analysis of whether it is best for external policy-makers or the users of a common property resources to attempt to devise systems of rules for how that resource is to be managed, arguing that "rules combine in a configurational or interactive manner." What she means is that "the way one rules operates is affected by other rules", so that "[ $t]$ he results predicted in one situation, using one rule, are dependent upon the other rules simultaneously in use" (E. Ostrom 1986 2014: 108, 110, 104; also see E. Ostrom and V. Ostrom [2004] 2014: 77). The implication for theorists, or policy-makers, is that they "need to specify a set of rules, rather than a single rule, when attempting to ask what consequences are produced by changes in a particular rule" (E. Ostrom [1986] 2014: 115; also see E. Ostrom [1986] 2014: 101-110, and E. Ostrom ([1998] 2014: 146-47, 150). But according to Ostrom this requirement may well imply that policy-makers face severe epistemic challenges that they are incapable of meeting. The reason is that once the number of rules increases beyond even a very small number, the variety of possible rule combinations requiring analysis increases exponentially, quickly surpassing what even expert analysis might reasonably be expected to cope with. "Given the logic of combinatorics," Ostrom (1999: 523) writes, "it is impossible ... to conduct a complete analysis of the expected performance of all the potential rule changes that could be made by the individuals served by a self-organised resource governance system trying to improve its performance."

In the case of innovation systems, such interdependency between rules means that the impact of one rule on the capacity of the system to generate and diffuse new knowledge depends on the other rules in the system, as documented in the literature on 'institutional complementarities' (Hall and Soskice 2001: 18-21; Crouch 2010; also see Bergek et al. 2010: 129-30; Dias et al. 2014: 1072-73, 1078-79). For instance, the impact on the performance of the innovation system of a new rule that makes it easier for innovative firms to gain credit and thereby fund their efforts to develop new technologies will be different depending on whether the rules governing the education system ensure that the firms are also able to acquire the skilled workers required for the development and implementation of the technologies in question.

It is epistemic problems such as those identified by Hayek and Ostrom that arguably lie behind at least some of the difficulties highlighted in the passages from Smith, from Weber and Truffler, and from Edler and Fagerberg quoted at the start of this section. Those authors all allude to the way that policy-makers require detailed knowledge about how the various parts of an innovation system interact, something which — as Smith concedes - imposes significant informational demands upon policy-makers. Faced with such demands, both Austrians such as Hayek and members of the Bloomington School such as Elinor Ostrom would argue that policy-makers ought seriously 
consider a change of emphasis, away from having experts undertake ever more elaborate empirical studies designed to provide that knowledge towards an approach that allows more scope for the relevant organisations within the innovation system to experiment with devising their own rule-based solutions to so-called system failures. ${ }^{9}$

On this view, instead of there being a presumption in favour of policy being devised and implemented by central government, more serious consideration/greater weight ought to be given to a polycentric approach to the creation of the rules that govern the innovation system. Under a polycentric system of governance, people - the users of the resource, in the case of common property, or the managers of the various organisations involved in innovation - have the authority to experiment with different configurations of (operational) rules governing their interactions. This autonomy enables them to try out different rule combinations, in the light of their local knowledge of the particular circumstances they face, in an attempt to discover systems of rules that work well for them. Elinor Ostrom and other members of the Bloomington School have shown that allowing groups of actors to develop their own rules often brings advantages compared to top-down approaches to rule-formation; affording different groups the autonomy to experiment with different configurations of rules enabling different groups to experiment makes it possible to try out more combinations of rules, to compare their performance and to identify which works best. In this way, according to the Ostroms, polycentric systems can facilitate a process of social learning whereby the parallel efforts of different groups of people to devise configurations of rules may in the end make it possible to discover better combinations than if the systems of rules in question were designed using a top-down, or monocentric or constructivist approach (Ostrom 1990, 1999: 497, 519-28, 2005).

\section{Conclusions}

The view advanced here suggests that — as seen from the vantage point provided by IS theory -innovation policy should focus more than hitherto on identifying and creating the conditions conducive to social learning about effective combinations of rules governing the activities that contribute to innovation. Such an approach coheres well not only with the Ostroms' work on polycentric systems of governance, but also with suggestions that there needs to be a move away from more prescriptive. 'command and control' approaches towards policy in favour of encouraging and enabling appropriate rules through what the Ostroms refer to as 'public entrepreneurship' (Aligica 2014: 30 70, Aligica 2019: 19-91). It also has affinities with 'bottom-up' perspectives on public policy derived from complexity theory (Page 2011; Colander and Kupers 2014, Vorley

\footnotetext{
${ }^{9}$ The difficulties appear only greater once it is recalled that, like complex systems more generally, innovation systems are hierarchical, in the sense that the parts of one kind of innovation system may themselves be complex systems, formed of components that stand in certain relations to one another and so possessing their own distinctive structure and emergent properties. For example, national innovation systems may be composed of regional innovation systems and are themselves formed by sectoral innovation systems (Asheim and Gertler 2005; Breschi and Malerba 1997; Dosi and Nelson 2018: 71). On this view, the world consists of a nested hierarchy of complex systems, with the lower-level systems existing within the context of higher-level systems in a hierarchy of levels of complexity (Page 2011: 26; Colander and Kupers 2014: 50). But this raises the question of the level at which intervention is to take place, on which see Smith (2017).
} 
and Nelles 2019: 10-14; also see Edler and Fagerberg 2017) and with the literature on 'experimentalist governance', which emphasises the importance of adopting trial-anderror strategies for devising policy goals and rules within a multi-level governance architecture as a means of dealing with uncertainty in policy-making (Sanderson 2009; Sabel and Zeitlin 2012). ${ }^{10}$ All of these approaches acknowledge the epistemic challenges posed by the complexity of innovation systems and the importance of experimenting with a diversity approaches to policy if those challenges are to be met.

Of course, in many respects innovation already is a polycentric process, involving multiple actors crafting and enforcing governance rules that enable them to marshal the resources, in particular the knowledge, required to ensure the creation and widespread diffusion of new products and production processes (and to solve from the bottom up the various collective action problems involved in that process) (Shivakumar 2017; Potts 2018; also see Chaminde and Edquist 2010: 101; Bergek et al. 2010: 118). Significantly, as Harper and Endres (2016: 209) have noted, actors' efforts to forge such governance arrangements are guided by feedback in the form of the profits or losses earned by the ventures facilitated by the rules in question. This helps the actors in question to refine and improve their choice of rules. It is important that policy-makers recognise this, and not intervene in ways that see them unthinkingly usurp the scope for actors to devise their own rules. The appropriate role for government, on this view, lies in providing the broader institutional framework, in particular the (ideally, abstract, stable, general) over-arching rules of property and contract, within which such endogenous, bottom-up rule formation can take place (Harper 2018: 17-19).

Finally, it is worth recalling that, notwithstanding their differences, the IS and Austrian approaches share a good deal of common ground (see section 3 above). There are, as a result, areas of research where there is scope for the Austrians and supporters of the IS approach to use one another's insights and collaborate in fruitful ways. Three examples will briefly be mentioned here. The first centres on the scope for using Austrian capital theory to undergird the analysis of innovation as a complex, creative process of capital combination and dissolution driven by entrepreneurs (whose contribution is sometimes, it has recently been argued, given insufficient weight by the IS approach) (Harper and Endres 2016; Sandström et al. 2019). Second, while Austrians have set great store by physical capital, they have arguably paid too little attention to human capital. Here, they can benefit from contributions that, while emerging fromand being oriented towards - the IS literature have in fact developed an analysis of the role of institutions in coordinating, or failing to coordinate, the accumulation of physical and (heterogenous) human capital that have a distinctively Austrian flavor (Amendona and Vona 2012; Lewis 2019: section 5.3, 2020: section 5). The third, and final, possible line of intellectual exchange that opens up at the interface of the two approaches concerns the need, widely-acknowledged by both, to develop a more appropriate set of standards or benchmarks by reference to which performance of innovation systems, and the scope for government policy, can be assessed (Schmidt 2018; Futon and Martin 2019; Endres and Harper 2020: 172-75).

\footnotetext{
${ }^{10}$ The similarity is perhaps unsurprising, given that both the Ostroms and the advocates of experimental governance were influenced by Dewey's work on policies as experiments (Sabel and Zeitlin 2012; Aligica 2014: 166-99).
} 
Acknowledgements I'm grateful for the support of the Centre for the Study of Governance and Society at King's College London and for a referee's helpful comments.

Open Access This article is licensed under a Creative Commons Attribution 4.0 International License, which permits use, sharing, adaptation, distribution and reproduction in any medium or format, as long as you give appropriate credit to the original author(s) and the source, provide a link to the Creative Commons licence, and indicate if changes were made. The images or other third party material in this article are included in the article's Creative Commons licence, unless indicated otherwise in a credit line to the material. If material is not included in the article's Creative Commons licence and your intended use is not permitted by statutory regulation or exceeds the permitted use, you will need to obtain permission directly from the copyright holder. To view a copy of this licence, visit http://creativecommons.org/licenses/by/4.0/.

\section{References}

Aligica, P. (2014). Institutional diversity and political economy: The Ostroms and beyond. Oxford: Oxford University Press.

Aligica, P. (2019). Public entrepreneurship, citizenship, and self-governance. Oxford: Oxford University Press.

Amendona, M., \& Vona, F. (2012). Coordinating the accumulation of physical and human Capital in Different Institutional Settings. Economics of Innovation and New Technology, 21, 631-653.

Antoneli, C. (2017). Endogenous innovation: The creative response. Economics of Innovation and New Technology, 26, 689-718.

Arrow, K. (1962). Economic welfare and the allocation of resources for invention. In R. Nelson (Ed.), The rate and direction of inventive activity. Princeton University Press: Princeton.

Asheim, B. T., \& Gertler, M. S. (2005). The geography of innovation: Regional innovation systems. In J. Fagerberg, D. C. Mowery, \& R. Nelson (Eds.), The Oxford handbook of innovation. Oxford: Oxford University Press.

Bergek, A., Jacobsson, S., Hekkert, M. and Smith, K. (2010). 'Functionality of Innovation Systems as a Rationale for and Guide to Innovation Policy.' In R. Smits, S. Kuhlman and P. Shapira (eds.), Innovation policy: Theory and Practice. An International Handbook. London: Edward Elgar.

BIS (2011). Innovation and Research Strategy for Growth. BIS Economics Paper No. 15. London: Department for Business, Innovation and Skills. Available online at: http://group-global. org/sites/default/files/publications/Innovation\%20and\%20Research\%20Strategy\%20for\%20Growth_3. pdf. Accessed 6th October 2017.

Breschi, S., \& Malerba, F. (1997). Sectoral innovation systems: Technological regimes, Schumpeterian dynamics, and spatial boundaries. In C. Edquist (Ed.), Systems of Innovation: Technologies, institutions. London and Washington: Pinter.

Chaminde, C. and Edquist, C. (2010). 'Rationales for Public Policy Intervention in the Innovation Process: Systems of Innovation Approach.' In R. Smits, S. Kuhlman and P. Shapira (eds.), Innovation policy: Theory and Practice. An International Handbook. London: Edward Elgar.

Colander, D., \& Kupers, R. (2014). Complexity and the art of public policy: Solving Society's problems from the bottom up. Princeton: Princeton University Press.

Crouch, C. (2010). Complementarity. In G. Morgan, J. Campbell, C. Crouch, O. Pedersen, \& R. Whitely (Eds.), The Oxford handbook of comparative institutional analysis. Oxford: Oxford University Press.

DBIS (2014). The Case for Public Support of Innovation: At the Sector, Technology and Challenge Area Levels. London: Department of Business, innovation and skills. Available online at: https://www.gov. uk/government/uploads/system/uploads/attachment_data/file/334369/BIS_14_852_The_Case_for_ Public_Support_of_Innovation.pdf. Accessed 28th September 2017.

Dias, M., Pedrozo, E., \& Nunes da Silva, T. (2014). The innovation process as a complex structure with multilevel rules. Journal of Evolutionary Economics, 24, 1067-1084.

Dosi, G. (1988). Sources, procedures, and microeconomic effects of innovation. Journal of Economic Literature, 26, 1120-1171.

Dosi, G. and Nelson, R. (2018). 'Technological Advance as an Evolutionary Process.' In R. Nelson, G. Dosi, C. Helfat, A. Pyka, P. Saviotti, K. Lee, K. Dopfer, F. Malerba and S. Winter (2018). Modern evolutionary economics: An overview. Cambridge: Cambridge University Press. 
Dosi, G., Freeman, C., Nelson, R., Silverberg, G., \& Soete, L. (Eds.). (1988). Technical change and economic theory. London: Pinter Publishers.

Edquist, C. (1997a). Preface. In C. Edquist (Ed.), Systems of Innovation: Technologies, institutions. London and Washington: Pinter.

Edquist, C. (1997b). Systems of Innovation Approaches - Their emergence and characteristics. In C. Edquist (Ed.), Systems of Innovation: Technologies, institutions. London and Washington: Pinter.

Edquist, C. (2005). Systems of Innovation: Perspectives and challenges. In J. Fagerberg, D. Mowrey, \& R. Nelson (Eds.), The Oxford handbook of innovation. Oxford: Oxford University Press.

Edler, J., \& Fagerberg, J. (2017). Innovation policy: What, why, and how. Oxford Review of Economic Policy, 33, 2-23.

Endres, A., \& Harper, D. (2020). Economic development and complexity: The role of recombinant capital. Cambridge Journal of Economics, 44, 157-179.

Fagerberg, J. (2017). Innovation policy: Rationales, lessons and challenges. Journal of Economic Surveys, 31, 497-512.

Freeman, C. (1987). Technology policy and economic performance: Lessons from Japan. London: Frances Pinter.

Furton, G., \& Martin, A. (2019). Beyond market failure and government failure. Public Choice, 178, $197-216$.

Gaus, J. (2007). Social complexity and evolved moral principles. In P. McNamara (Ed.), Liberalism, conservatism, and Hayek's idea of spontaneous order. London: Palgrave Macmillan.

Government Economic Service (2014). GES Group on Growth: Innovation. London: Government Economic Service. Available online at: https:/www.gov.uk/government/uploads/system/uploads/attachment data/file/370187/bis-14-1169-government-economic-service-group-on-growth-innovation.pdf. Accessed $2^{\text {nd }}$ March 2018.

Hall, P., \& Soskice, D. (2001). An introduction to varieties of capitalism. In P. Hall \& D. Soskice (Eds.), Varieties of capitalism: The institutional foundations of comparative advantage. Cambridge: Cambridge University Press.

Harper, D. (2018). Innovation and institutions from the bottom up: An introduction. Journal of Institutional Economics, 14, 975-1001.

Harper, D., \& Endres, A. (2016). Innovation, recombinant capital and public policy. Supreme Court Economic Review, 23, 193-219.

Harper, D., \& Lewis, P. (2012). New perspectives on emergence in economics. Journal of Economic Behavior and Organization, 82, 329-337.

Hayek, F.A. ([1945] 2014). 'The Use of Knowledge in Society.' In F.A. Hayek (2014), The Collected Works of F.A. Hayek, Volume 15: The Market and other Orders. Edited by B. Caldwell. Chicago: The University of Chicago Press.

Hayek, F.A. ([1948] 2014). 'The Meaning of Competition.' In F.A. Hayek (2014), The Collected Works of F.A. Hayek, Volume 15: The Market and other Orders. Edited by B. Caldwell. Chicago: The University of Chicago Press.

Hayek, F.A. ([1967] 2014). 'Notes on the Evolution of Systems of Rules of Conduct.' In F.A. Hayek (2014), The Collected Works of F.A. Hayek, Volume 15: The Market and other Orders. Edited by B. Caldwell. Chicago: The University of Chicago Press.

Hayek, F.A. ([1968] 2014). 'Competition as a Discovery Procedure.' In F.A. Hayek (2014), The Collected Works of F.A. Hayek, Volume 15: The Market and other Orders. Edited by B. Caldwell. Chicago: The University of Chicago Press.

Hayek, F. A. (1976). Law, legislation and liberty: A new statement of the Liberal principles of justice and political economy. Volume II: The mirage of social justice. London and New York: Routledge.

Kirzner, I. M. (1992). The meaning of market process. In The meaning of the market process: Essays in the development of modern Austrian economics. London and New York: Routledge.

Kirzner, I. M. (2000). The driving force of the market: Essays in Austrian economics. London and New York: Routledge.

Kline, S. and Rosenberg, N. (1986). 'An Overview of Innovation'. In R. Landau and N. Rosenberg (eds.), The Positive Sum Strategy: Harnessing Technology for Economic Growth (Washington, DC.: National Academy of Sciences).

Levinthal, D. (1997). Adaptation on rugged landscapes. Management Science, 43, 934-950.

Lewis, P. (2013). On Hayek, social theory and the contrastive explanation of social order. Critical Review, 25, $386-408$.

Lewis, P. A. (2015). Notions of order and process in Hayek: The significance of emergence. Cambridge Journal of Economics, 39, 1167-1190. 
Lewis, P. A. (2016). Systems, levels of organisation and structural properties: The influence of Ludwig von Bertalanffy on the development of the work of F.a. Hayek. Research in the History of Economic Thought and Methodology, 34A, 125-159.

Lewis, P. A. (2017). 'The Ostroms and Hayek as Theorists of Complex Adaptive Systems: Commonality and Complementarity.' Advances in Austrian Economics, 22: 35-66. Available online at: https://papers.ssrn. com/sol3/papers.cfm?abstract id=2940972. Accessed 18 th June 2018.

Lewis, P.A. (2019). Technicians and Innovation: A System Theoretic Approach and Literature Review. London: The Gatsby Charitable Foundation. Available online at: https://papers.ssrn.com/sol3/papers. cfm?abstract_id=3405406. Accessed $20^{\text {th }}$ June 2019.

Lewis, P. (2020). 'Developing Technician Skills for Innovative Industries: Theory, Evidence from the UK Life Sciences Industry, and Policy Implications.' British Journal of Industrial Relations. Online first: doi.org/ 10.1111/bjir. 12532

Lundvall, B.-Å. (Ed.). (1992). National Innovation Systems: Towards a theory of innovation and interactive learning. London: Pinter Publishers.

Lundvall, B.-Å., \& Johnson, B. (1994). The learning economy. Journal of Industry Studies, 1, $23-42$.

Metcalfe, S. (1995). Technology systems and technology policy in an evolutionary framework. Cambridge Journal of Economics, 19, 25-46.

Metcalfe, S. (2005). Systems failure and the case for innovation policy. In P. Llerna \& M. Matt (Eds.), Innovation policy in a knowledge-based economy: Theory and practice. Berlin: Springer.

Metcalfe, S. (2007). Innovation systems, innovation policy and restless capitalism. In F. Malerba \& S. Brusoni (Eds.), Perspectives on innovation. Cambridge: Cambridge University Press.

Metcalfe, S., \& Ramlogan, R. (2004). Limits to the economy of knowledge and knowledge of the economy. Futures, 37, 655-674.

Metcalfe, S., Foster, J., \& Ramlogan, R. (2006). Adaptive economic growth. Cambridge Journal of Economics, 30, 7-32.

McQuade, T. (2010). Science and The Sensory Order. Advances in Austrian Economics, 13, 23-56.

McQuade, T., \& Butos, W. (2003). Order-dependent knowledge and the economics of science. Review of Austrian Economics, 16, 133-152.

Mytelka, L., \& Smith, K. (2002). Policy learning and innovation theory: An interactive and co-evolving process. Research Policy, 31, 1467-1479.

Nelson, R. (1959). The simple economics of basic scientific research. Journal of Political Economy, 67, 4991.

Nelson, R. (1980). 'Production sets, technological knowledge, and R\&D: Fragile and overworked constructs for analysis of productivity growth?' American Economic Review, Papers and Proceedings, 70: 62-67.

Nelson, R. (Ed.). (1993). National Systems of innovation: A comparative study. Oxford: Oxford University Press.

Nelson, R. (2018). 'Economics from an Evolutionary Perspective.' In R. Nelson, G. Dosi, C. Helfat, A. Pyka, P. Saviotti, K. Lee, K. Dopfer, F. Malerba and S. Winter (2018). Modern evolutionary economics: An overview. Cambridge: Cambridge University Press.

Nelson, R., \& Rosenberg, N. (1993). Technical innovation and National Systems. In R. Nelson (Ed.), National Systems of innovation: A comparative study. Oxford: Oxford University Press.

Nelson, R., \& Winter, S. (1982). An evolutionary theory of economic change. Cambridge: Harvard University Press.

OECD (1997a). Oslo Manual: Proposed Guidelines for Collecting and Interpreting Technological Innovation Data. 2nd edition. Paris: Organisation for economic co-operation and development. Available online at: http://www.oecd.org/sti/inno/2367580.pdf. Accessed 10 th June 2018.

OECD (1997b). National Innovation Systems. Paris: Organisation for economic co-operation and development. Available online at: http://www.oecd.org/science/inno/2101733.pdf. Accessed 10 th June 2018.

OECD (2002). Dynamising National Innovation Systems. Paris: Organisation for economic co-operation and development. Available online at: https://read.oecd-ilibrary.org/industry-and-services/dynamisingnational-innovation-systems 9789264194465-en\#page1 accessed $10^{\text {th }}$ June 2018.

OECD (2005): Oslo Manual: Proposed Guidelines for Collecting and Interpreting Technological Innovation Data. 3rd edition. Paris: Organisation for economic co-operation and development. Available online at: http://www.oecd-ilibrary.org/docserver/download/9205111e.pdf?expires=1507624240\&id=id\&accname= guest\&checksum=B3C73436D830EEED3ED084F1B4AA2FD3. Accessed 10th October 2017.

Ostrom, E. ([1986] 2014). 'An agenda for the study of institutions.' In F. Sabetti and P. Aligica (eds.), Choice, rules and collective action: The Ostroms on the study of institutions and governance. Colchester: ECPR Press, 48.

Ostrom, E. (1990). Governing the Commons Cambridge: Cambridge university press. 
Ostrom, E. ([1998] 2014), 'A behavioral approach to the rational choice theory of collective action.' In F. Sabetti and P. Aligica (eds.), Choice, rules and collective action: The Ostroms on the study of institutions and governance. Colchester: ECPR Press.

Ostrom, E. (1999). Coping with tragedies of the commons. Annual Review of Political Science, 2, $493-535$.

Ostrom, E. (2005). Understanding institutional diversity. Princeton: Princeton University Press./.

Ostrom, E. and V. Ostrom ([2004] 2014). 'The quest for meaning in public choice.' In F. Sabetti and P. Aligica (eds.), Choice, rules and collective action: The Ostroms on the study of institutions and governance. Colchester: ECPR Press, 63, 105, 147.

Page, S. (2011). Diversity and complexity. Princeton: Princeton University Press.

Potts, J. (2018). Governing the innovation commons. Journal of Institutional Economics, early view., 14, $1025-1047$.

Rosenberg, N. (1982). Inside the black box: Technology and economics. Cambridge: Cambridge University Press.

Sabel, C., \& Zeitlin, J. (2012). Experimentalist governance. In D. Levi-Faur (Ed.), The Oxford handbook of governance. Oxford: Oxford University Press.

Sanderson, I. (2009). Intelligent policy making for a complex world: Pragmatism, evidence and learning. Political Studies, 57, 699-719.

Sandström, C., Wennberg, K., \& Karlson, N. (2019). Bureaucrats or Markets in Innovation Policy? Stockholm: Ratio Institute.

Schmidt, P. (2018). Market failure vs. system failure as a rationale for economic policy? A critique from an evolutionary perspective. Journal of Evolutionary Economics, 28, 785-803.

Sharif, N. (2006). Emergence and development of the National Innovation Systems Concept. Research Policy, 35, 745-766.

Shivakumar, S. (2017). 'Innovation as a Collective Action Challenge.' In P. Aligica, P. Lewis, and V. Storr (eds.), The Austrian and Bloomington Schools of Economics. Advances in Austrian Economics, Volume 22. Bingley: Emerald Publishing.

Smith, K. (2000). Innovation as a systemic phenomenon: Rethinking the role of policy. Enterprise and Innovation Management Studies, 1, 73-102.

Smith, K. (2017). Innovating for the global commons: Multilateral Collabortation in a polycentric world. Oxford Review of Economic Policy, 33, 49-65.

Tarko, V. (2015). Polycentric structure and informal norms: Competition and coordination within the scientific community. Innovation: The European Journal of Social Science Research, 28, 63-80.

von Hippel, E. (1988). The Sources of Innovation New York: Oxford university press.

von Hippel, E. (2015). Democratising innovation: The evolving phenomenon of user innovation. Journal für Betriebswirtschaft, 55, 63-78.

Vona, F., \& Consoli, D. (2014). Innovation and skill dynamics: A life-cycle approach. Industrial and Corporate Change, 24, 1393-1415.

Vorley, T. and Nelles, J. (2019). 'From silos to systems: insights and implications for productivity policy.' Productivity and Innovation Network, Evidence Review 12. Available online at https://productivityinsightsnetwork.co.uk/app/uploads/2019/05/Vorley-and-Nelles_SystemsApproach 2019.pdf. Accessed 12 $2^{\text {th }}$ August 2019.

Weber, K., \& Truffler, B. (2017). Moving innovation systems research to the next level: Towards an integrative agenda. Oxford Review of Economic Policy, 33, 101-121.

Woolthius, R., Lankhuizen, M., \& Gilsing, V. (2005). A system failure framework for innovation policy design. Technovation, 25, 609-619.

Publisher's note Springer Nature remains neutral with regard to jurisdictional claims in published maps and institutional affiliations. 